\title{
PENERAPAN PRINSIP KEHATI-HATIAN BANK DALAM PENCAIRAN DANA NASABAH DIHUBUNGKAN DENGAN UNDANG-UNDANG TENTANG PERBANKAN
}

\author{
Eri Eka Sukarini, \\ Shofi Juliastuti \\ Universitas Wiralodra \\ Email : eri_ekasukarini@yahoo.com, \\ shofijuliastuti10@gmail.com
}

\begin{abstract}
Banks, especially commercial banks, are not only financial intermediaries from those with surplus funds to those with deficit funds, but are also the financial foundation of every country engaged in business activities and the various services provided. Banks serve and launch payment system mechanisms for all sectors of the economy. As a financial institution, bank activities are based on the trust of customers who can be accounted for by the bank. The Bank as an Intermediary institution carries out its business activities based on banking principles and rules, one of which is the Prudential Principle which must be applied. The methodology used in this research is a normative juridical approach, namely by collecting library data by examining library materials or secondary legal materials. In this case, by examining the legal issues contained in Court Decision Number 38/Pdt.G/2017/PN.Idm and Act Number 10, 1998. The precautionary principle as a form of legal protection for customers indirectly to anticipate losses to customers. Which should be implemented properly to maintain customer trust, but in its implementation the precautionary principle has not been applied optimally. This has been encountered in one of the cases where the bank was deemed not to have maximally implemented the prudential principles. Proof (validation) of the system, the Bank should apply the precautionary principle but in its implementation the Bank causes losses to customers and the loss of customer trust in the Bank.
\end{abstract}

Keywords: Customer Fund, Fund Disbursement, Banking System.

\section{PENDAHULUAN}

Perbankan sebagai salah satu lembaga keuangan yang mempunyai nilai strategis di dalam perekonomian suatu negara ${ }^{1}$, baik dalam menyerasikan maupun mengembangkan perekonomian dan pembangunan nasional. Lembaga perbankan dimaksudkan sebagai perantara (Intermediary) antara pihak yang mempunyai kelebihan dana (surplus of funds) dan pihak yang memerlukan atau kekurangan dana (luck of funds) $)^{2}$.

\footnotetext{
1 Muhammad Djumhana, HukumPerbankan di Indonesia, Citra Aditya, Jakarta, 1993, hlm.1.

2 Hermansyah, Hukum Perbankan Nasional Indonesia, Jakarta, 2006, hlm. 3.
} 
1. Sebagai lembaga intermediasi (financial intermediary), bank mempunyai tiga fungsi utama $^{3}$, yaitu bank sebagai lembaga yang menghimpun dana (funding) masyarakat dalambentuk simpanan, bank sebagai lembaga yang menyalurkan dana (lending) ke masyarakat dalam bentuk kredit danbank sebagai lembaga yang melancarkan transaksi perdagangan dan peredaran uang.

2. Dengan fungsinya, bank mempertemukan dua pihak yang berbeda kepentingan, baik dalam menghimpun penanaman dana, maupun dalam pelayanan transaksi keuangan dan lalu lintas pembayaran. Dua pihak ini antara lain adalah hubungan antara bank dan nasabah yang dalam kegiatannya didasarkan pada dua unsur yang saling terkait, yaitu hukum dan kepercayaan ${ }^{4}$.

3. Kepercayaan sangat penting dalam kegiatan usaha bank, karena kepecayaan dapat menimbulkan keyakinan. Para pihak terlebih dahulu harus menumbuhkan kepercayaan di antara mereka, bahwa satu sama lain akan memenuhi janji yang di sepakati atau melaksanakan prestasinya dikemudian hari. Dengan kepercayaan kedua belah pihak mengikatkan dirinya kepada kontrak yang mempunyai kekuatan mengikat sebagai undang-undang sebagaimana di tentukan pasal 1338 ayat (1) KUHPerdata ${ }^{5}$.

4. Begitupun dengan kegiatan penyimpanan dana, yaitu salah satu dari tiga fungsi utama bank yakni kegiatan usaha lembaga keuangan dalam menarik dan mengumpulkan dana-dana dari masyarakat dan menampungnya dalam bentuk simpanan, giro, tabungan deposito/ surat berharga lainnya ${ }^{6}$. Pada prinsipnya kegiatan penyimpanan dana tersebut dilandasi oleh kepercayaan, yang mana masyarakat atau nasabah berdasarkan kepercayaannya melakukan kegiatan menyimpan dana dibank berdasarkan perikatan atau kontraktual yang mengikat sebagai Undang-Undang antara keduanya.

5. Dari kontraktual atas kepercayaan tersebut, menjadikan bank harus berhati-hati dalam melaksanakan kegiatan usahanya. Dalam menjalankan fungsinya bank harus menjalankan kegiatan usahanya berdasarkan Asas dan Prinsip-prinsip Perbankan

3 Ibid

4 Permadi Gandapradja, Dasar dan Prinsip Pemhawasan Bank, Jakarta, PT Gramedia Pustaka Utama, 2004, hlm. 2

5 Hermansyah, Perwujudan Asas Kepercayaan Dalam Pengaturan Kegiatan Usaha Bank, Program Magister Ilmu Hukum, Universitas Tanjungpura Pontianak, 2015, hlm. 3.

6 Frianto Pandla, Manajemen Dana dan Kesehatan Bank, Rineka Cipta, Jakarta, 2012, hlm. 7 
yang menjadi dasar hubungan antara bank dan nasabah. Asas dan Prinsip perbankan tertuang dalam Pasal 2 Undang-Undang nomor 7 tahun 1999 tentang perbankan yang menyatakan bahwa Perbankan Indonesia dalam melakukan usahanya berasaskan demokrasi ekonomi dengan menggunakan prinsip kehati-hatian. ${ }^{7}$ Selain prinsip kehati-hatian ada juga prinsip-prinsip lainnya yang wajib diterapkan bank dalam melaksanakan kegiatan usaha perbankan. Prinsip-prinsip lain tersebut antara lain ialah Prinsip kepercayaan atau fiduciary principle, prinsip kerahasiaan atau conifideniality principle, dan prinsip mengenal nasalah atau Know how custumer ${ }^{8}$.

6. Prinsip kehati-hatian sebagai salah satu prinsip dalam kegiatan usaha bank di Indonesia wajib diterapkan atau di laksanakan oleh bank. Prinsip kehati-hatian (prudential principle) tersebut mengharuskan pihak bank untuk selalu waspada dan hati -hati dalam menjalankan usahanya, dalam arti harus selalu konsisten dan taat dalam melaksanakan peraturan perundang-undangan dibidang perbankan berdasarkan profesionalisme dan itikad baik ${ }^{9}$.

7. Substansi mengenai prinsip kehati-hatian, selain telah disebutkannya pada Pasal 2 Undang-Undang Nomor 10 Tahun 1998 juga disebutkan secara eksplisit pada Pasal 29 ayat (2) dan ayat (3) Undang-Undang Nomor 10 Tahun 1998 tentang Perbankan, yakni "Bank wajib memelihara tingkat kesehatan bank sesuai dengan ketentuan kecukupan modal, kualitas aset, kualitas manajemen, likuiditas, rentabilitas, solvabilitas dan aspek lain yang berhubungan dengan usaha bank, dan wajib melakukan kegiatan usaha sesuai dengan prinsip kehati-hatian”. Ketentuan tersebut menunjukan bahwa adanya rasa tanggung jawab dari pihak bank terhadap para nasabahnya dan ini bertujuan agar ada rasa percaya dan rasa aman dari nasabah terhadap terhadap bank tersebut.

8. Penerapan Prinsip kehati-hatian diwajibkan oleh bank dalam semua kegiatan yang dilakukan oleh bank termasuk juga dalam menjalankan kebijakan-kebijakan internal bank. Hal ini dimaksudkan agar bank terhindar dari kendala-kendala serta dampak negatif dan menghindari risiko-risiko yang timbul dari seluruh kegiatan usaha

\footnotetext{
7 Pasal 2 Undang-Undang Nomor 7 Tahun 1999 Tentang Perbankan

8 Trisadini P. Usanti dan Dr. Abd. Shomad, Hukum Perbankan, Kencana, Surabaya, 2016, hlm.19.

9 Liabrintika Oktaviani Gunawan, dkk, Akibat Hukum Pelanggaran Prinsip Kehati-hatian dalam Pemberian Kredit oleh Bank, Hukum Bisnis Fakultas Hukum, Universitas Udayana, hlm. 2.
} 
bank $^{10}$. Salah satu risiko-risiko bank adalah Risiko Opesional. Keadaan ini akan berdampak buruk pada manajemen dan pengelolaan intern bank, yang nantinya akan mempengaruhi kepercayaan nasabah terhadap bank serta kesehatan dan kinerja dari bank itu sendiri.

9. Disamping dalam kegiatannya didasarkan pada perjanjian, hukum dan kepercayaan serta perenapan asas dan prinsip-prinsip bank, dalam implementasinya praktik perbankan dewasa ini, penerapan prudential banking principles khususnya yang merupakan andalan bagi upaya pembinaan kepercayaan nasabah dan sekaligus sebagai sarana perlindungan masyarakat dalam penyimpanan dana tanpaknya belum secara maksimal diterapkan ${ }^{11}$. Hal ini terbukti dengan adanya salah satu peristiwa hukum yang terjadi pada putusan Nomor 38/Pdt.G/2017/PN.Idm yang diperkuat dengan putusan pidana Nomor 96/Pid.B/2017/Pn.Idm.

10. Uraian singkat peristiwa hukum Pada putusan Nomor 38/Pdt.G/2017/PN.Idm ialah gugatan ganti rugi atas perbuatan melawan hukum yang diawali dengan Penggugat yang merupakan pemilik buku Tabungan di BRI Cabang Indramayu dengan Nomor Rekening 0028-01-023059-50-3 dan pemilik Kartu Anjungan Tunai Mandiri (ATM) dengan nomor kartu ATM 5221842048202300 pernah menitipkan Buku Tabungan berikut Kartu ATM Bank BRI tersebut kepada Tergugat I yakni suami dari Penggugat yang telah resmi bercerai dengan Akta Cerai Nomor 6169/AC/2016/PA/Im. Tegugat I telah mengambil uang secara tunai di Teller BRI Cabang Indramayu yakni yang bertugas pada saaat itu ialah turut Tergugat I, dengan menggunakan surat kuasa dan memalsukan tanda tangan Penggugat serta menggunakan KTP Penggugat yang dipalsukan seolah-olah Penggugat memberikan kuasa kepada Tergugat I yang mengambil dan menerima uang tabungan tersebut ${ }^{12}$.

11. Selain mengambil uang secara tunai di Teller BRI Cabang Indramayu, Tergugat I juga telah merubah atau melakukan pergantian terhadap kartu ATM milik Penggugat dengan tujuan mempermudah transaksi dalam penarikan uang maupun pemindahbukuan atau transfer. Perlu diketahui bahwa dalam melakukan pergantian Kartu ATM milik Penggugat, Tergugat I dibantu oleh Tergugat II yang merupakan

\footnotetext{
${ }^{10}$ Ibid

${ }^{11}$ Marulak Pardede, Likuidasi Bank Perlindungan Nasabah, PustakaSinar Harapan, Jakarta, 1998, hlm. 4.

${ }^{12}$ Putusan Pengadilan Negeri Indramayu Nomor 38/Pdt.G/2017/PN.Idm.
} 
teman dari Tergugat I yang bertindak seolah-olah sebagai istrinya, dengan mengisi Formulir permohonan pergantian kartu ATM BRI dari tabungan atas nama Penggugat dan memalsukan tanda tangan Penggugat pada kolom tandatangan pemohon. Pergantian ganti kartu ATM tersebut dilakukan di BRI Cabang Indramayu dengan Customer Servive yang bertugas yakni turut Tergugat II.

12. Setelah proses pergantian kartu ATM tersebut, Tergugat I telah menarik uang secara tunai melalui ATM yang seluruhnya berjumlah Rp 22.430.500,- (dua puluh dua juta empat ratus riga puluh ribu lima ratus rupiah), serta transfer rekening ke rekening lain dengan jumlah Rp. 471.356.430,- (empat ratus tujuh puluh satu juta tiga ratus lima puluh enam ribu empat ratus tiga puluh rupiah). Dengan adanya perbuatan tersebut Penggugat secara materiil mengalami kerugian dengan jumlah Rp.568.786.930,- (lima ratus enam puluh delapan juta tujuh ratus delapan puluh enam ribu sembilan ratus tiga puluh rupiah). Dan atas perbuatan tersebut Tergugat I telah dinyatakan bersalah karna melakukan Pemalsuan surat yang telah di Putus pada putusan Pengadilan Negeri Indramayu Nomor 96/Pid.B/2017/PN.Idm ${ }^{13}$.

13. Tergugat III yakni Kepala Cabang Bank BRI Tbk KC BRI Indramayu beserta turut Tergugat I (Teller yang bertugas pada saat pengambilan uang), dan Turut tergugat II (Customer Service yang bertugas pada saat perubahan kartu ATM) diduga telah melakukan kelalaian atas ketidaktelitiannya dan tidak profesionalnya dalam menjalannya kegiatan bank khususnya dalam hal validasi atau pengecekan keabsahan dalam melakukan transaksi.

14. Penerapan Prinsip kehati-hatian yang dinyatakan belum dilakukan secara maksimal dalam peristiwa hukum diatas, menjadikan timbulnya dampak buruk pada manajemen dan pengelolaan intern bank. Kerugian yang terjadi akibat adanya kegagalan proses dan prosedur bank yakni dalam melaksanakan pekerjaan yang tidak sesuai dengan kebijakan dan prosedur termasuk kegiatan check dan control dalam memastikan kebenaran dan ketaatan (risiko operasional) ${ }^{14}$ yang terjadi dalam peristiwa tersebut menjadikan kepercayaan nasabah terhadap bank telah hilang. Bank yang seharusnya dapat memberikan perlindungan terhadap nasabahnya dengan penerapan kehati-hatian dalam menjalankan segala transaksinya namum pada

\footnotetext{
${ }^{13}$ Ibid

${ }^{14} \mathrm{http}: / /$ carajadikaya.com/risiko-operasional-perbankan/ diunduh pada tanggal 15 Maret 2021
} 


\section{JURTE-ISSN: 2723-0147}

implementasinya hubungan atas kepercayaan tersebut dalam penerapan prinsip kehati-hatiannya belum dilaksanakan secara maksimal.

15. Berdasarkan uraian yang telah dikemukakan di atas, maka peneliti dalam hal ini tertarik untuk mengkaji lebih dalam dan mngadakan peneliatian yang berjudul

"Penerapan Prinsip Kehati-hatian Bank Dalam Pencairan Dana Nasabah Dihubungkan Dengan Undang-Undang Tentang Perbankan”.

\section{IDENTIFIKASI MASALAH}

Berdasarkan hal-hal yang telah diuraikan diatas, maka permasalahan yang hendak dikemukakan dalam penulisan tesis ini adalah sebagai berikut :

1. Penerapan Prinsip Kehati-hatianBank BRI Pada Putusan Nomor 38/PDT.G/2017/PN.IDM

2. Pertanggungjawaban Bank Terhadap Adanya Kelalaian Dalam Pelaksanaan Prinsip Kehati-Hatian

\section{METODE}

Metode pendekatan yang digunakan dalam penelitian ini adalah metode pendekatan yuridis normatif yaitu dengan pengumpulan data secara kepustakaan dengan meneliti bahanbahan pustaka atau bahan-bahan hukum sekunder. Dalam hal ini dengan mengkai permasalahan dari segi hukum yang terdapat dalam Putusan Pengadilan nomor Nomor 38/Pdt.G/2017/PN.Idm dan Undang-Undang Nomor 10 Tahun 1998 tentang perubahan atas Undang-Undang nomor 7 Tahun 1992 tentang Perbankan.

\section{LANDASAN TEORI}

Berdasarkan Identifikasi masalah diatas, maka untuk menyelesaiakan permasalahan tersebut teori yang dipakai sebagai pisau analisis adalah Teori Negara Hukum.

Istilah negara hukum merupakan terjemahan dari istilah "rechtsstaat". Istilah lain yang digunakan dalam alam hukum Indonesia adalah the rule of law, yang juga digunakan untuk maksud "negara hukum”. Notohamidjojo menggunakan kata-kata "...maka timbul juga istilah negara hukum atau rechtsstaat." Djokosoetono mengatakan bahwa "negara 


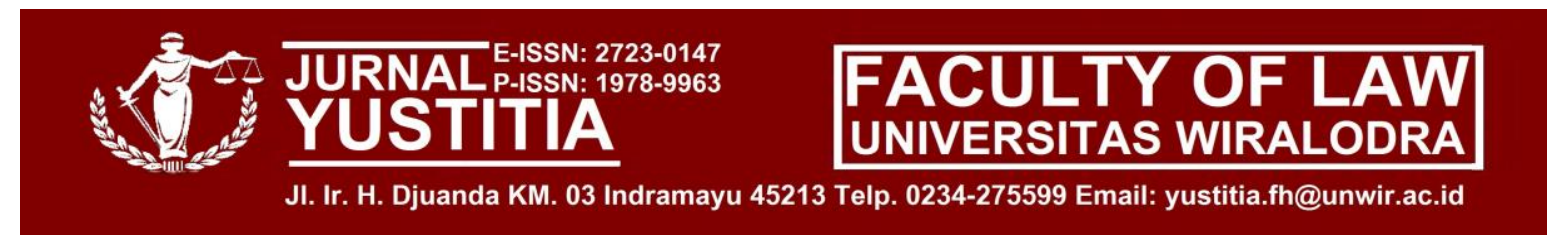

hukum yang demokratis sesungguhnya istilah ini adalah salah, sebab kalau kita hilangkan democratische rechtsstaat, yang penting dan primair adalah rechtsstaat ${ }^{, 15}$.

Sementara itu, Muhammad Yamin menggunakan kata negara hukum sama dengan rechtsstaat atau government of law, sebagaimana kutipan pendapat berikut ini: "polisi atau negara militer, tempat polisi dan prajurit memegang pemerintah dan keadilan, bukanlah pula negara Republik Indonesia ialah negara hukum (rechtsstaat, government of law) tempat keadilan yang tertulis berlaku, bukanlah negara kekuasaan (machtsstaat) tempat tenaga senjata dan kekuatan badan melakukan sewenang-wenang"16.

Cita Negara Hukum di Indonesia menjadi bagian yang tak terpisahkan dari perkembangan gagasan kenegaraan Indonesia sejak kemerdekaan. Meskipun dalam pasalpasal UUD 1945 sebelum perubahan, ide Negara hukum itu tidak dirumuskan secara eksplisit, tetapi dalam Penjelasan ditegaskan bahwa Indonesia menganut ide "rechtsstaat".Pasal 1 ayat (3) Undang-Undang Negara Republik Indonesia Tahun 1945. Pasal ini menghendaki bahwa penyelenggaraan pemerintahan didasarkan atas prinsipprinsip hukum untuk membatasi kekuasaan pemerintah dalam dan ini artinya kekuasaan negara melalui aparatnya dibatasi oleh hukum (Rechtsstaat), bukan didasarkan atas kekuasaan (Machtsstaat).

Guna menjamin tertib hukum, penegakan hukum, dan tujuan hukum, fungsi kekuasaan kehakiman atau lembaga peradilan berperan penting, terutama fungsi penegakan hukum dan fungsi pengawasan. Dalam penegakan hukum atau pelaksanaan hukum sering merupakan penemuan hukum atau pembentukan hukum.

Dalam hal kaitannya dengan permasalahan yang diangkat dalam penulisan ini, menyatakan bahwa Indonesia merupakan negara hukum, hal ini telah tercantum dalam UUD 1945. Dalam pelaksanaan tujuan negara penerapan negara hukum yang mana seluruh kegiatan masyarakat Indonesia diatur oleh hukum dengan memenuhi syarat-syarat yang ditentukan, dalam kegiatan perbankanpun pelaksanaannya berdasarkan hukum. Hukumhukum tentang perbankan mengatur secara jelas tentang bagaimana kegiatan bank dilakukan, termasuk juga dalam aturan-aturan secara internal yang mengikat sebagai hukum bagi para pihak yang berkepentingan.

\footnotetext{
15 O. Notohamidjojo, Makna Negara Hukum, Jakarta: Badan Penerbit Kristen, 1970, hlm. 27.

16 Muhammad Yamin, Proklamasi dan Konstitusi Republik Indonseia, Ghalia Indonesia, Jakarta, 1982,
} hlm. 72 . 


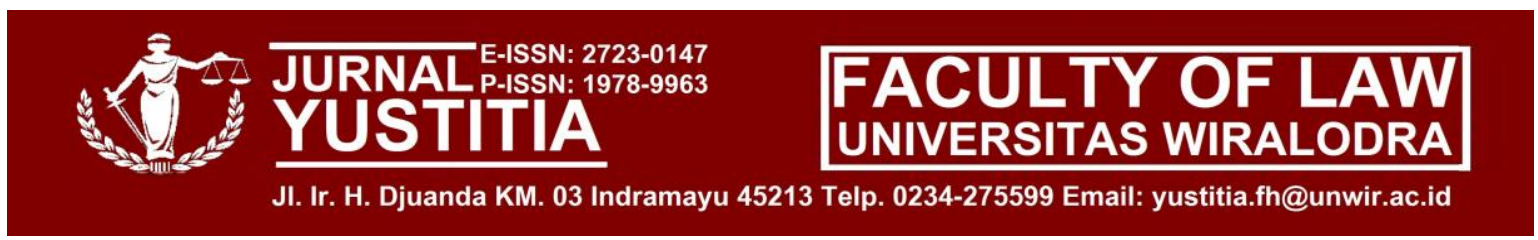

Teori yang digunakan ini, didukung juga dengan landasan asas atau teori yang digunakan yaitu Dalam Pasal 2 Undang-Undang No 7 Tahun 1992 tentang Perbankan menetapkan bahwa Perbankan Indonesia dalam melaksanakan kegiatan usahanya berdasarkan asas demokrasi ekonomi dan menggunakan prinsip kehati-hatian. Untuk mempertegas makna asas demokrasi ekonomi ini penjelasan umum dan penjelasan Pasal 2 menyatakan bahwa yang dimaksud dengan demokrasi ekonomi adalah demokrasi ekonomi berdasarkan Pancasila dan Undang- Undang Dasar 1945. Demokrasi ekonomi ini tersimpul dalam Pasal 33 Undang dasar 1945, yaitu perekonomian disusun sebagai usaha bersama berdasarkan asas kekeluragaan.

Teori yang sering dipergunakan di dalam praktek perbankan adalah Prinsip kehatihatian (Prudential Regulation,) dalam hukum perbankan prudential regulation dikategorikan sebagai "a seamless web" yang bertujuan untuk mencapai suatu system perbankan yang sehat dan efisien. Prudential regulation merupakam aturan main yang merupakan kerangka hukum, sosial dan politik. Dalam konsep prudential regulation ukuran sangan ditentukan oleh akibat tindakan yang dilakukan oleh para pelaku bisnis bank dalam mengelola bisnisnya untuk mencapai suatu bank yang sehat, efisien, tangguh bersaing dan dapat berperan mendukung pembangunan ekonomi nasional.

Untuk di Indonesia sendiri prinsip kehati-hatian bank pada bank yang selalu memperhatikan prundential regulation akan peduli terhadap konsekuensi dan tindakan jangka panjangnya, baik untuk kepentingan bank yang dikelolanya dan sistem perbankan secara keseluruhan ${ }^{17}$. Prinsip kehatihatian telah diakomodir dalam ketentuan normatif, sebagaimana tercantum dalam Undang-Undang Nomor 7 tahun 1992 Tentang Perbankan Pasal 2 berbunyi:

"Perbankan Indonesia dalam melakukan usahanya berasaskan demokrasi ekonomi dengan mengunakan prinsip kehati-hatian.”

Pasal 29 Ayat (1),(2),(3), dan (4) Bab V tentang Pembianaandan Pengawasan Bank dari Undang-Undang Nomor 10 Tahun 1998 Tentang Perubahan Atas Undang- Undang Nomor 7 Tahun 1992 Tentang Perbankan:

\section{Pasal 29 Ayat (1):}

\footnotetext{
17 Johannes Ibrahim (1). Hubungan Kontraktual Dalam Kontrak Bisnis, Kolerasi antara ranah Hukum Privat Dan Hukum Publik, Bandung: Universitas Pasundan, Jurnal Ilmu Hukum Litigasi, Volume 8, number 1, 2007, hlm. 95.
} 
"Pembinaan dan pengawasaan bank dilakukan oleh Bank Indonesia"

Pasal 29 Ayat (2):

"Bank Wajib memelihara tingkat kesehatan bank sesuai dengan kententuan, kecukupan modal,kualitas asset, kualitas manajemen, likuiditas, rentabilitas, solvabilitas, dan aspek lain yang berhubungan dengan usaha bank, dan wajib melakukan kegiatan usaha sesuai dengan prinsip kehati-hatian"

\section{Pasal 29 Ayat (3):}

"Dalam memberikan Kredit atau Pembiayaan berdasarkan Prinsip Syariah dan melakukan kegiatan usaha lainnya, bank wajib menempuh cara-cara yang tidak merugikan bank dan kepentingan nasabah yangmempercayakan dananya kepada bank."

\section{Pasal 29 Ayat (4)}

"Untuk kepentingan nasabah, bank wajib menyediakan informasi mengenai kemungkinan timbulnya risiko kerugian sehubungan dengan transaksi nasabah yang dilakukan melalui bank."

Bank dalam menjalankan aktivitasnya berpegang pada prinsip - prinsip penting, antara lain:

\section{Prinsip Kepercayaan}

Prinsip kepercayaan adalah suatu asas yang melandasi hubungan antara bank dan nasabah bank. Bank berusaha dari dana masyarakat yang disimpan berdasarkan kepercayaan, sehingga setiap bank perlu menjaga kesehatan banknya dengan tetap memelihara dan mempertahankan kepercayaan masyarakat. Prinsip kepercayaan diatur dalam Pasal 29 ayat (4) Undang-Undang No 10 Tahun 1998 Tentang Perbankan.

\section{Prinsip Kehati-hatian (prudential principle)}

Prinsip kehati-hatian adalah suatu prinsip yang menegaskan bahwa bank dalam menjalankan kegiatan usaha baik dalam penghimpunan terutama dalam penyaluran dana kepada masyarakat harus sangat berhati-hati. Tujuan dilakukannya prinsip kehati-hatian ini agar bank selalu dalam keadaan sehat menjalankan usahanya dengan baik dan mematuhi ketentuan-ketentuan dan norma-norma hukum yang berlaku di dunia perbankan. Prinsip kehati-hatian tertera dalam Pasal 2 dan Pasal 29 ayat (2) Undang-Undang No 10 Tahun 1998 tentang Perbankan.

\section{Prinsip Kerahasiaan (secrecy principle)}


Prinsip kerahasiaan bank diatur dalam Pasal 40 sampai dengan Pasal 47 A UndangUndang No 10 Tahun 1998 tentang Perbankan. Menurut Pasal 40 bank wajib merahasiakan keterangan mengenai nasabah penyimpan dan simpanannya. Namun dalam ketentuan tersebut kewajiban merahasiakan itu bukan tanpa pengecualian. Kewajiban merahasiakan itu dikecualikan untuk dalam hal-hal untuk kepentingan pajak, penyelesaian utang piutang bank yang sudah diserahkan kepada badan Urusan Piutang dan Lelang/Panitia Urusan Piutang Negara (UPLN/PUPN), untuk kepentingan pengadilan perkara pidana, dalam perkara perdata antara bank dengan nasabah, dan dalam rangka tukar menukar informasi antar bank.

\section{Prinsip Mengenal Nasabah (know your customer principle)}

Prinsip mengenal nasabah adalah prinsip yang diterapkan oleh bank untuk mengenal dan mengetahui identitas nasabah memantau kegiatan transaksi nasabah termasuk melaporkan setiap transaksi yang mencurigakan. Prinsip mengenal nasabah nasabah diatur dalam Peraturan Bank Indonesia No. 3/10/PBI/2001 tentang Penerapan Prinsip Mengenal nasabah. Tujuan yang hendak dicapai dalam penerapan prinsip mengenal nasabah adalah meningkatkan peran lembaga keuangan dengan berbagai kebijakan dalam menunjang praktik lembaga keuangan, menghindari berbagai kemungkinan lembaga keuangan dijadikan ajang tindak kejahatan dan aktivitas ilegal yang dilakukan nasabah, dan melindungi nama baik dan reputasi lembaga keuangan.

Dari beberapa Teori dan asas yang disampaikan, dalam hal kaitannya dengan penerapan prinsip kehati-hatian yang dianggap belum dilaksanakan secara maksimal yang diperkuat dengan adanya peristiwa hukum yang terjadi, dengan aturan yang telah ditetapkan dan asas serta prinsip yang wajib diterapkan dapat dibuktikan bahwa adanya kelalaian yang terjadi dalam peristiwa hukum yang diangkat dalam penulisan ini, dan nantinya dapat diketahui proses penyelesaian dan pertanggungjawaban yang harus dilakukan oleh pihak bank tersebut.

\section{HASIL DAN PEMBAHASAN}

\section{A. Penerapan Prinsip Kehati-hatianBank BRI Pada Putusan Nomor 38/PDT.G/2017/PN.IDM}


Lembaga keuangan perbankan mampu berperan aktif dalam menjaga kestabilan perekonomian. Bukan sekedar sebagai lembaga perantara keuangan (intermediary financial) dari pihak yang surplus dana (surplus of fund) kepada pihak yang defisit dana (lack of funds) tetapi lembaga keuangan perbankan khususnya bank umum merupakan fondasi dari keuangan setiap negara. Salah satu pelayanan jasa yang bank adalah penghimpun dana dari masyarakat yaitu berupa simpanan giro, deposito, tabungan serta bentuk lainnya. Dari hubungan tersebut terlihat adanya hubungan yang sangat sinergis antara bank dengan nasabahnya. Nasabah yang menggunakan bank sebagai bagian dari kehidupan perekonomiannya, tentu dalam hubungannya menaruh kepercayaan yang tinggi terhadap bank. Oleh karna itu sebagai lembaga penghimpun dan penyalur dana masyarakat, dalam menjalankan usahanya bank harus berlandaskan pada asas dan prinsip-prinsip perbankan. Salah satu prinsip yang wajib diterapkan dalam usaha perbankan adalah Prinsip kehatihatian. Sesuai dengan isi Undang-undang RI Nomor 7 tahun 1992 tentang perbankan, pelaksanaan prinsip kehati-hatian perbankan didasarkan pada fungsi utama perbankan sebagai lembaga penghimpun dan penyalur dana masyarakat ${ }^{18}$.

Prinsip kehati-hatian perbankan (prudent banking principle) merupakan suatu asas atau prinsip yang menyatakan bahwa bank atau lembaga dalam menjalankan fungsi dan kegiatan usahanya wajib menerapkan prinsip kehati-hatian (prudent) dengan mengenal customer dalam rangka melindungi dana masyarakat yang dipercayakan padanya, dengan mengharapkan kadar kepercayaan masyarakat terhadap lembaga keuangan tetap tinggi, sehingga masyarakat bersedia dan tidak ragu-ragu menyimpan dananya di bank.

Penerapan prinsip Kehati-hatian Bank dilakukan dengan selalu konsisten dalam melaksanakan peraturan perundang-undangan dibidang perbankan berdasarkan profesionalisme dan itikad baik untuk mencegah timbulnya risiko-risiko kerugian dari suatu kebijakan dan kegiatan usaha yang dilakukan oleh bank. Prinsip ini telah dinormatifkan dalam peraturan perbankan di Indonesia misalnya dalam Pasal 2 UU No.7 Tahun 1992 perbahan UU No.10 Tahun 1998 tentang Perbankan. Penormatifan prinsip kehati-hatian dalam UU No.7 Tahun 1992 jo UU No.10 Tahun

\footnotetext{
${ }^{18}$ Malayu S.P Hasibuan, Dasar-Dasar Perbankan, Bumi Aksara, Jakarta, 2001, hlm. 4.
} 
1998 tentang Perbankan berarti suatu penegasan yang secara implicit bahwa prinsip kehati-hatian ini sebagai salah satu asas terpenting yang wajib diterapkan dan dilaksanakan oleh bank dalam menjalankan kegiatan usahanya ${ }^{19}$. Penegasan prinsip kehati-hatian juga diatur dalam Pasal 29 ayat (2) UU No.7 Tahun 1992 jo UU No.10 Tahun 1998 tentang Perbankan yang menegaskan: "Bank wajib memelihara tingkat kesehatan bank sesuai dengan ketentuan kecukupan modal, kualitas aset, kualitas manajemen, likuiditas, rentabilitas, solvabilitas, dan aspek lain yang berhubungan dengan usaha bank, dan wajib melakukan kegiatan usaha sesuai dengan prinsip kehati-hatian" 20 .

Perlunya penerapan prinsip kehati-hatian bank dalam menjalankan kegiatan usahanya, dalam hal penerapannya seringkali bank atau pihak bank lalai dalam menjalankan prinsip kehati-hatian tersebut, hal ini terdapat dalam salah satu peristiwa hukum yang terjadi pada duduknya perkara putusan nomor 38/PDT.G/2017/PN/Idm.

Pada duduknya perkara putusan nomor 38/PDT.G/2017/PN/Idm nasabah (penggugat) merasa dirugikan akibat adanya perbuatan melawan hukum yang dilakukan oleh mantan suaminya (tergugat I) dan temannya (tergugat II) yang telah melakukan penarikan uang secara berturut turut melalui Teller Bank BRI Cabang Indramayu (turut tergugat I) dan telah melakukan pergantian kartu ATM milik nasabah melalui Costumer Service turut tergugat II) dengan melakukan pemalsuan tanda tangan serta menggunakan surat kuasa palsu. Perlu diketahui pemalsuan tanda tangan telah terbukti dengan adanya hasil putusan pidana nomor 96/Pid.B/2017/PN.Idm dengan terdakwa adalah mantan suami Penggugat yakni Tergugat I yang telah terbukti melakukan pemalsuan tanda tangan dengan ancaman pidana 2 tahun penjara.

Dalam kegiatan transaksi yang dilakukan dengan pemalsuan tanda tangan dan menggunakan surat kuasa palsu tersebut, dalam surat gugatan penggugat menyatakan bahwa Turut tergugat I yakni Teller bank BRI Cabang Indramayu, Turut Tergugat II yakni Costumer service Bank BRI Cabang Indramayu serta Tergugat III yakni Kepala Cabang PT. Bank Rakyat Indonesia (Persero) Tbk KC BRI Indramayu telah

\footnotetext{
${ }^{19}$ Hermansyah, Op.Cit, h. 147

${ }^{20}$ Sutan Remy Syahdeini, Perbankan Islam (Dalam Kedudukannya Dalam tata Hukum di Indonesia), Jakarta, Utama Pustaka Grafika), hlm. 172.
} 
melakukan pelanggaran Prinsip Kehati-hatian bank karna dianggap telah melakukan kelalaian, ketidaktelitian serta tidak profesionalnya dalam menjalanjakan kegiatan transaksi penarikan dana serta pergantian kartu ATM milik penggugat yang dilakukan oleh Tergugat I dan Tergugat II.

Berdasarkan prosdur penarikan tunai dalam Buku Pedoman Operasional telah ditentukan sebagai berikut :

1. Menerima slip penarikan, butab dan asli kartu identitas dari nasabah;

2. Memeriksa kebenaran, kelengkapan dan keabsahan slip penarikan. Identitas nasabah dan mencocokan tanda tangan pada slip penarikan dengan tanda tangan pada tabungan;

3. Melakukan entry data penarikan pada sistem;

4. Mengesahkan dan memvalidasi slip penarikan dan mencetak transaksi pada butab sesuai dengan kewenangan;

5. Mencocokan kebenaran tapak validasi dengan data pada slip penarikan dan membubuhkan paraf pada akhir tapak validasi;

6. Apabila jumlah penarikan diatas kewenangan teller, minta override kepada pejabat lebih tinggi sesuai dengan kewenangan;

7. Menandatangani slip penarikan sebagai checker/signer;

8. Menghitung dan menyerahkan uang berikut butab kepada nasabah;

9. Menyimpan slip penarikan sebagai bukti pembukuan untuk dicocokan dengan AATR.

Tercantum juga dalam "KETENTUAN UMUM TABUNGAN BRI BRITAMA" yang secara jelas ada tercantum pada buku tabungan BritAma milik Penggugat. (Vide Ketentuan umum tabungan BRI BritAma angka 5 bagian penyetoran dan penarikan, bunyi ketentuan tersebut yakni :

5. Setiap penarikan tunai yang diwakilkan hanya dapat dilakukan di Kantor Bank tempat membuka rekening dengan melampirkan Surat Kuasa dari Penabung \& copy kartu identitas Penabung dan Penerima Kuasa. Penerima kuasa harus menunjukan asli kartu identitasnya dan asli kartu identitas penabung."

Dalam hal kaitannya dengan duduknya perkara dalam putusan nomor 38/Pdt.G/2017/PN.Idm, penggugat dalam hal ini telah menitipkan buku tabungannya 
sebelumya kepada Tergugat I, tergugat I telah melakukan penarikan secara tunai melalui Turut Tergugat I, berdasarkan ketentuan umum buku tabungan BRI Britama, penarikan tunai yang diwakilkan harus dilakukan dengan melampirkan surat kuasa dari Penabung dan dalam hal ini Tergugat I telah membuat surat kuasa palsu untuk transaksinya. Turut tergugat I yakni merupakan Teller BRI Cabang Indramayu berdasarkan ketentuan prosdur penarikan tunai dalam Buku Pedoman Operasional dianggap telah memeuhi ketentuan tersebut. Namun perlu diketahui dalam hal penarikan uang yang dilakukan oleh pihak lain dengan menggunakan surat kuasa, dalam hal kepastiannya perlu adanya konfirmasi terlebih dahulu kepada pihak nasabah.

1. Menerima slip penarikan, butab dan asli kartu identitas dari nasabah;

Penarik, yakni tergugat I telah mengisi slip penarikan disertai buku tabungan asli milik Penggugat serta identitas Penggugat.

2. Memeriksa kebenaran, kelengkapan dan keabsahan slip penarikan. Identitas nasabah dan mencocokan tanda tangan pada slip penarikan dengan tanda tangan pada tabungan;

Pemeriksaan kebenaran yang dilakukan dengan disertai surat kuasa dilakukan dengan konfirmasi kepada pihak nasabah, mencocokan tanda tangan pada surat kuasa dengan buku tabungan, yang dalam hal ini pihak Teller telah lalai dalam pelaksanaannya.

3. Melakukan entry data penarikan pada sistem;

4. Mengesahkan dan memvalidasi slip penarikan dan mencetak transaksi pada butab sesuai dengan kewenangan;

Pengesahan dan memvalidasi slip hanya dilakukan dengan penyesuaian tanda tangan dan data slip dengan data dibank, yang dalam hal ini pihak bank lalai dalam pengecekan keabsahannya.

5. Mencocokan kebenaran tapak validasi dengan data pada slip penarikan dan membubuhkan paraf pada akhir tapak validasi;

Tindakan pembuktian yang dilakukan pihak bank yang dilakukan dengan cara tahap, proses, prosedur, sistem, mekanisme dan pengawasan tidak mencapai hasil yang diinginkan dan hal ini yang mengakibatkan timbulnya kerugian bagi nasabah. 
6. Apabila jumlah penarikan diatas kewenangan teller, minta override kepada pejabat lebih tinggi sesuai dengan kewenangan;

7. Menandatangani slip penarikan sebagai checker/signer;

8. Menghitung dan menyerahkan uang berikut butab kepada nasabah;

9. Menyimpan slip penarikan sebagai bukti pembukuan untuk dicocokan dengan AATR.

Bersumber dari beberapa poin diatas, Turut Tergugat I yakni Teller Bank BRI Cabang Indramayu berdasarkan putusan Nomor 38/PDT.G/ 2017/PN.Idm dianggap telah melakukan tugas secara sesuai dan berdasarkan pedoman Prosedur yang ada yang mana penarikan tidak dilakukan oleh pemilik dalam hal ini Penggugat), maka turut Tergugat I meminta kepada yang melakukan penarikan untuk menggunakan mekanisme surat kuasa dengan persyaratan identitas dari pemberi kuasa (Penggugat) dan penerima kuasa (Tergugat I). Atas hal tersebut, syarat-syarat yang telah ditentukan oleh Tergugat III melalui Turut Tergugat I telah dipenuhi oleh Penggugat maupun Tergugat I. Namun berdasarkan implementasinya penulis berpendapat bahwa prosedur yang dilakukan turut tergugat I dan Tergugat III belum dapat dilakukan secara maksimal karna sistem kegiatan pembuktian (validasi) yang dilakukan tidak dapat mencapai hasil yang baik yang mana dalam kegiatan pembuktian yang dilakukan pihak bank menjadikan lolosnya tindak kejahatan mengakibatkan timbulnya kerugian bagi nasabah.

Perlu diketahui dalam hal adanya pemalsuan surat kuasa dan pemalsuan tanda tangan, terkait keabsahan dari tanda tangan yang digukan Tergugat I dianggap bukan sebagai wewenang Bank, namun asli atau tidaknya tanda tangan yang digunakan dalam transaksi Tergugat I hanya dapat dibuktikan melalui pihak yang berwenang. Dan hal ini telah terbukti berdasarkan keputusan hakim nomor 96/Pid.B/2017/Pn.Idm bahwa Tergugat I dinyatakan terbukti telah melakukan pemalsuan tanda tangan atas peristiwa tersebut.

Transaksi yang kedua yakni pergantian kartu ATM milik Penggugat (Nasabah). Berdasarkan prosedur penggantian kartu ATM yang telah kadarluasa 
sebagaimana berdasarkan ketentuan internal dalam Buku Pedoman Operasional telah ditentukan sebagai berikut:

a. Menerima asli butab asli kartu identitas dari nasabah, dan asli kartu ATM yang telah kadarluasa;

b. Mengisi formulir pergantian kartu ATM (FR01) dan mencocokan tanda tangan pada formulir penarikan ATM dengan tanda tangan pada butab;

c. Melakukan verifikasi data yang telah diisi oleh nasabah serta mencocokan data pada sistem;

d. Apabila kelengkapan persyaratan pergantian kartu ATM telah sesuai dan memenuhi persyaratan Costumer Service melakukan proses entry data penggatian kartu ATM pada sistem;

e. Meminta persetujuan atasan supervior atau amo) yang sedang menjabat agar kartu ATM yang baru daat diterbitkan dengan membawa kelengkapan persyaratan nasabah serta formulir penggatian kartu ATM;

f. Setelah mendapatkan persetujuan atasan Costumer Service melakukan aktivasi kartu ATM yang baru dengan menggunakan password Costumer Service serta meminta password pada atasan;

g. Setelah kartu ATM yang baru telah aktif Customer service meminta nasabah untuk meminta pin yang baru;

h. Nasabah menandatangani buku register sebagai bukti bahwa ATM yang baru telah diterima oleh nasabah;

i. Menyimpan formulir penggantian kartu ATM untuk dicocokan dengan report harian penerbitan kartu ATM;

Dari beberapa ketentuan Internal diatas, Berdasarkan putusan hakim nomor 38/Pdt.G/2017/PN.Idm Turut Tergugat II dianggap telah melaksanakan prosedur dalam hal penggatian kartu ATM yang telah kadarluasa sesuai dengan persyaratan yaitu asli buku tabungan, asli kartu identitas nasabah dan asli kartu ATM yang telah kadarluasa. Dengan melakukan penggantian kartu ATM tersebut, konfirmasi yang dilakukan Turut Tergugat II dilakukan dengan menyebutkan nama ibu kandung untuk dicocokan dengan sistem, dan diketahui bahwa hal tersebut cocok. 
Namun menurut hasil penelitian penulis berpendapat bahwa Turut Tergugat II dianggap lalai dalam menjalankan Prosedur Operasional, dalam implementasinya pergantian kartu ATM dilakukan oleh pihak lain (Tergugat II) yang mana merupakan bukan nasabah. Dalam hal syarat-syarat yang diajukan adalah asli buku tabungan, asli kartu identitas nasabah dan asli kartu ATM yang telah kadarluasa, seharusnya dari kegiatan tersebut Tutut Tergugat II dapat mengetahui bahwa kegiatan pergantian kartu ATM bukan dilakukan oleh pemilik nasabah karna disitu tercantum kartu Identitas dalam persyaratannya. Dalam hal konfirmasi yang dilakukan Turut Tergugat II dilakukan dengan menyebutkan nama ibu kandung dan pengecekan data yang diakhiri dengan tanda tangan, Proses pembuktian dari sistem validasi kegiatan perubahan kartu ATM pun dianggap tidak memenuhi hasil yang baik sehingga tindak kejahatan dapat lolos dan menimbulkan kerugian bagi nasabah.

Dari beberapa perstiwa yang terjadi diatas Tutut Tergugat I, Turut Tergugat II dan Tergugat III dianggap telah lalai dalam melaksanakan Prinsip kehati-hatian Bank karna tidak hati-hati dalam melaksanakan kegiatan perbankan.

Indonesia adalah Negara Hukum, berdasarkan Pasal 1 Ayat (3) UndangUndang Dasar Republik Indonesia Tahun 1945 menyatakan "Negara Indonesia adalah Negara Hukum”, yang berarti segala kegiatan yang dilakukan oleh masyarakat Indonesia semua diatur oleh Hukum, begitupun sama halnya dengan kegiatan Perbankan, dalam pelaksanaannya semua diatur oleh Hukum.

Prinsip kehati-hatian telah diakomodir dalam ketentuan normatif, sebagaimana tercantum dalam Undang-Undang Nomor 7 tahun 1992 Tentang Perbankan Pasal 2 dan Pasal 29 Ayat (1),(2),(3), dan (4) Bab V tentang Pembianaan dan Pengawasan Bank dari Undang-Undang Nomor 10 Tahun 1998 Tentang Perubahan Atas Undang- Undang Nomor 7 Tahun 1992 Tentang Perbankan.

Dalam hal kaitannya dengan peristiwa hukum yang terjadi dalam putusan hakim nomor 38/Pdt.G/2017/PN.Idm, penerapan prinsip kehati-hatian Bank yang harus diterapkan berdasarkan Undang-Undang yang berlaku namun dalam implementasinya Penerepan Prinsip kehati-hatian dalam peristiwa ini belum secara maksimal diterapkan. 
Penerepan prinsip kehati-hatian yang wajib diterapkan untuk menghindari risiko-risiko bank, namun dengan adanya peristiwa hukum yang terjadi pada putusan Nomor 38/Pdt.G/2017/PN.Idm beberapa risiko muncul diakibatkan adanya kelalaian pihak bank. Salah satunya yakni Risiko Operasional yakni Risiko yang timbul akibat ketidakcukupan dan/atau tidak berfungsinya proses internal, kesalahan manusia, kegagalan sistem, dan/atau adanya kejadian eksternal yang mempengaruhi operasional Bank. Terkait peristiwa tersebut sumber risiko yang muncul yakni diakibatkan oleh sumber daya manusia, proses, dan sistem yang tidak dapat memenuhi hasil yang baik dalam hal ini adalah dalam penerapan Standar Operasional Prosedur dan dalam hal pembuktian (validasi) sistem yang akhirnya dapat merugikan nasabah dan hilangnya kepercayaan Nasabah terhadap Bank.

Bank yang seharusnya menerapkan prinsip kehati-hatian sesuai dengan yang diatur dalam Undang-Undang Nomor 10 Tahun 1998 tentang perubahan atas Undang-Undang Nomor 7 Tahun 1992 tentang perbankan, namun dalam Implementasinya penulis berpendapat bahwa pihak bank dianggap belum secara maksmilah menerapkan prinsip kehati-hatian didalam dunia Perbankan yang mengakibatkan timbulnya kerugian bagi nasabah dan hilangnya kepercayaan nasabah terhadap Bank.

\section{B. Pertanggungjawaban Bank Terhadap Adanya Kelalaian Dalam Pelaksanaan}

\section{Prinsip Kehati-Hatian}

Bank merupakan lembaga intermediasi, artinya kegiatan utamanya adalah penghimpun dana dan kegiatan penyaluran dana kepada masyarakat dengan mengutamakan kepercayaan yang dapat dipertanggungjawabkan oleh bank terhadap nasabahnya dalam menjalankan aktivitasnya yakni melakukan setiap kegiatan penyimpanan dan pengelolaan dana nasabah sesuai dengan hak-hak dan kewajiban hukumnya selaku lembaga penyedia jasa perbankan dengan melakukan pencatatan secara benar dan akurat baik secara elektronik maupun secara manual, tanpa melakukan tindakan-tindakan dan perbuatan diluar itu yang mengakibatkan atau setidaknya dapat mengakibatkan kerugian terhadap nasabah.

Peraturan perundang-Undangan di bidang perbankan ketentuan yang memberikan perlindungan hukum bagi nasabah bank selaku konsumen antara lain 
adalah dengan diintrodusirnya Lembaga Penjamin Simpanan (LPS) dalam UndangUndang Nomor 10 Tahun 1998, yaitu sebagai badan hukum yang menyelenggarakan kegiatan penjaminan atas simpanan Nasabah Penyimpan, melalui skim asuransi, dana penyangga, atau skim lainnya. Di tingkat teknis payung hukum yang melindungi nasabah antara lain adanya pengaturan mengenai penyelesaian pengaduan nasabah dan mediasi perbankan dalam Peraturan Bank Indonesia (PBI).

Kelalaian adalah perbuatan, dimana pembuatnya mengetahui akan kemungkinan terjadinya akibat yang merugikan orang lain. Berdasarkan asas kebebasan berkontrak salah satu pihak dengan persetujuan pihak yang lain dapat membatasi akibat-akibat yang mungkin timbul atau yang terjadi karena kelalaian.

Secara sederhana kelalaian dapat dikatakan merupakan salah satu bentuk kesalahan yang timbul karena pelakunya tidak memenuhi standar perilaku yang telah ditentukan.Kelalaian itu timbul karena faktor orangnya atau pelakunya.Dalam pelayanan perbankan faktor penyebab timbulnya kelalaian adalah kurangnya sistem elektronik yang bisa membaca transaksi rekening lama, atau kurangnya ketelitian pegawai bank pada waktu melaksanakan kewajibannya.

Suatu perbuatan dapat dianggap sebagai kelalaian apabila memenuhi unsur pokok sebagai berikut:

1. Adanya suatu perbuatan atau mengabaikan sesuatu yang mestiny dilakukan;

2. Adanya suatu kewajiban kehati-hatian;

3. Tidak dijalankan kewajiban kehati-hatian tersebut;

4. Adanya kerugian bagi orang lain;

5. Adanya hubungan sebab akibat antara perbuatan atau tidak melakukanperbuatan dengan kerugian yang timbul

Dalam dunia perbankan bentuk kelalaian dibagi menjadi dua macam yaitu:

a. Kelalaian dengan sengaja, maksud kelalaian yang disengaja yaitu kelalaianini dibuat sendiri oleh pelakunya atau dilakukan dengan sudahdirencanakan terlebih dahulu. Kelalaian dengan sengaja ini lembagapenjamin simpanan tidak bertanggung jawab atas kelalaian bank tersebut.

b. Kelalaian tidak sengaja, maksud dari kelalaian yang dilakukan dengan tidak sengaja tersebut ialah perbuatan yang tidak direncanakan ataudengan sendirinya timbul, misalnya adanya pembobolan uang nasabah. Kelalaian yang tidak 
sengaja ini lah pihak lembaga penjamin simpanan membantu bank tersebut atas kerugian nasabahtersebut. Peran Lembaga penjamin simpanan ini membantu bank mengganti kerugian yang diderita nasabah sebesar $100 \%$ dari kerugian nasabah.

Pada dasarnya suatu bank yang tidak melaksanakan prinsip kehati-hatian dan menyebabkan kerugian bagi nasabah penyimpan baik karena sengaja atau karena kelalaian adalah suatu bank yang tidak melaksanakan fungsi kepatuhan aturan bank.

Bank yang melakukan kelalaian yang menimbulkan kerugian bagi nasabah bank dianggap telah melanggar Pasal 29 ayat (4) Undang-Undang nomor 7 Tahun 1992 tentang Perbankan sebagaimana telah diubah dengan Undang-Undang nomor 10 Tahun 1998 yang mengatakan bank wajib menempuh cara-cara yang tidak merugikan kepentingan nasabah yang mempercayakan dananya kepada bank.Pengaturan mengenai akibat hukum dari kelalaian tersebut dipertanggungjawabkan dapat dibedakan menjadi dua, yakni pertanggungjawaban oleh bank dan pertanggungjawaban oleh pegawai bank.

Bank mau bertanggung jawab atas kelalaian apabila memenuhi unsur-unsur yang tertuang:

a. Adanya suatu perbuatan yang dilakukan oleh bank yang bertentangandengan ketentuan dalam Undang-undang perbankan dan perbuatantersebut tidak terdapat unsur pembenar.

b. Perbuatan yang dilakukan oleh bank menimbulkan kerugian bagi nasabahpenyimpan.

c. Adanya hubungan kausal antara perbuatan melanggar hukum yang dilakukan oleh bank dengan kerugian yang diderita oleh nasabahpenyimpan.

Dari ketiga unsur tersebut biasanya dilakukan oleh pegawai atau karyawan bank tersebut, berdasarkan Pasal 1603 KUH Perdata mengatur bahwa setiap karyawan mempunyai tanggung jawab untuk melakukan pekerjaa sebaik-baiknya dengan memperhatikan kepatutan. Selanjutnya didalam Pasal 1367 KUH Perdata menyebutkan bahwa bertanggung jawab atas kerugian karena perbuatan melanggar hukum yang dilakukan oleh karyawan bank yang berada dibawah perintah atau kekuasaanya mewajibkan bank yang bersangkutan turut bertanggungjawab atas tindakan atau kelalaian karyawan tersebut dan tentu saja pegawai bank dalam batas 
kewenangannya yang bertindak lalai atau kurang hati-hati dan menimbulkan kerugian badan hukum tetap terikat untuk bertanggung jawab secara pribadi. Karyawan atau pegawai bank yang melakukan kelalaian sehingga menyebabkan kerugian bagi nasabah dapat diberikan sanksi mulai dari teguran sampai dengan diberhentikan dengan tetap terhadapnya diwajibkan untuk mengganti kerugian yang ditimbulkannya.

\section{PENUTUP}

\section{A. Simpulan}

Dari uraian diatas dapatlah dikemukakan bahwa beberapa kesimpulan antara lain sebagaui berikut:

1. Pelaksanaan penerapan prinsip kehati-hatian Bank BRI cabang Indramayu pada putusan nomor 38/Pdt.G/2017/PN.Idm dianggap sudah sesuai berdasarkan ketentuan Standar Operasional Bank BRI. Namun berdasarkan hasil penelitian Penulis dalam Implementasinya kegiatan transaksi bank yang menimbulkan kerugian bagi nasabah ini berdasarkan Undang-Undang Nomor 10 Tahun 1998 tentang Perubahan atas Undang-Undang nomor 7 Tahun 1992 Penerapan prinsip kehati-hatian didunia perbankan belum secara maksimal dapat diterapkan, hal ini dikarenakan berdasarkan peristiwa hukum yang tercantum pada putusan nomor 38/Pdt.G/2017/PN.Idm dalam hal pelaksanaan Standar Operasional Prosedur yang tidak dijalankan secara hati-hati dan pelaksanaan Pembuktian (validasi) sistem dianggap tidak berjalan sesuai harapan dan hal ini yang menimbulkan loloskan kegiatan kejahatan dan timbulkan kerugian bagi nasabah.

2. Pertanggungjawaban bank terhadap adanya kelalaian dalam pelaksanaan prinsip kehati-hatian dapat dilakukan dengan pertanggungjawaban oleh bank dan pertanggungjawaban oleh pegawai bank. Berdasarkan Pasal 1367 KUH Perdata menyebutkan bahwa bertanggung jawab atas kerugian karena perbuatan melanggar hukum yang dilakukan oleh karyawan bank yang berada dibawah perintah atau kekuasaanya mewajibkan bank yang bersangkutan turut bertanggungjawab atas tindakan atau kelalaian karyawan tersebut dan pertanggung jawaban pegawai bank dalam batas kewenangannya yang bertindak lalai atau kurang hati-hati dan menimbulkan kerugian badan hukum tetap terikat untuk bertanggung jawab secara pribadi yakni dengan adanya pemecatan atau dengan ganti rugi. 


\section{B. Saran}

1. Penerapan Prinsip kehati-hatian yang belum secara maksimal diterapkan didunia perbankan, khususnya terkait peristiwa hukum yang terjadi dalam putusan hakim nomor 38/Pdt.G/217/PN.Idm yang mana pelaksanaan dari Standar Operasional Prosedur tidak secara hati-hati dilakukan dan pelaksanaan kegiatan pembuktian (validasi) tidak dapat dijalankan sesuai dengan keinginan dalam hal ini penulis berpendapat bahwa pihak Bank harus lebih secara maksimal lagi dalam menjalankan kegiatan usaha Bank dengan penerapan prinsip kehati-hatian dengan baik dan benar.

2. Pertanggung jawaban bank atas kelalaian terhadap penerapan prinsip kehati-hatian harusnya dapat secara jelas diterangkan dalam peraturan perundang-undangan dan seharusnya pelaksanaan dari pertanggung jawaban ini harus lebih secara maksimal diterapkan.

\section{DAFTAR PUSTAKA}

\section{A. Buku}

Frianto Pandla, Manajemen Dana danKesehatan Bank, Rineka Cipta, Jakarta, 2012)

Hermansyah, Hukum Perbankan Nasional Indonesia, Jakarta, 2006, hlm. 3.

Malayu S.P Hasibuan, Dasar-DasarPerbankan, Bumi Aksara, Jakarta, 2001.

Marulak Pardede, Likuidasi Bank Perlindungan Nasabah, Pustaka Sinar Harapan. Jakarta, 1998.

Muhammad Djumhana, Hukum Perbankan di Indonesia, Citra Aditya, Jakarta, 1993.

Muhammad Yamin, Proklamasidan Konstitusi Republik Indonseia, Ghalia Indonesia, Jakarta, 1982.

O. Notohamidjojo, Makna Negara Hukum, Badan Penerbit Kristen, Jakarta, 1970.

Permadi Gandapradja, Dasardan Prinsip Pemhawasan Bank, Jakarta, PT Gramedia Pustaka Utama, 2004.

Sutan Remy Syahdeini, Perbankan Islam (Dalam Kedudukannya Dalam tata Hukum di Indonesia), Utama Pustaka Grafiki, Jakarta.

Trisadini P. Usanti dan Dr. Abd. Shomad, Hukum Perbankan, Kencana, Surabaya, 2016. 
B. Jurnal:

Liabrintika Oktaviani Gunawan, dkk, Akibat Hukum Pelanggaran Prinsip Kehati-hatian dalam Pemberian Kreditoleh Bank, Hukum Bisnis Fakultas Hukum, Universitas Udayana, hlm. 2.

Hermansyah, Perwuju dan Asas Kepercayaan Dalam Pengaturan Kegiatan Usaha Bank, Program Magister Ilmu Hukum, Universitas Tanjungpura Pontianak, 2015, hlm. 3 .

Johannes Ibrahim (1). Hubungan Kontraktual Dalam Kontrak Bisnis, Kolerasi antara ranah Hukum Privat Dan Hukum Publik, Bandung: Universitas Pasundan, Jurnal Ilmu Hukum Litigasi, Volume 8, Number 1, 2007, hlm 95.

\section{Peraturan Perundang-undangan:}

- Pasal 2 Undang-Undang Nomor 7 Tahun 1999 Tentang Perbankan

- Putusan Pengadilan Negeri Indramayu Nomor: 38/Pdt.G/2017/PN.Idm. 